\title{
KOMBINASI METODE AHP DAN WEIGHT PRODUCT DALAM MENGANALISIS BENIH PADI UNGGUL
}

\author{
Raja Tama Andri Agus*, Mardalius ${ }^{1}$ \\ ${ }^{1}$ Sekolah Tinggi Manajemen Infromatika dan Komputer Royal \\ Email: *rajatamaandriagus@royal.ac.id
}

\begin{abstract}
Rice is the main requirement in processing various kinds of food, especially rice. The need for rice from year to year is even higher. This makes farmers have to increase the productivity of rice to be planted. However, farmers still use trial and error and rely on their hereditary habits in determining which rice seeds to plant. For example, there are still farmers who choose rice seeds based on cheap seed prices and those that have a faster harvest period. The impact of reducing the selling price of the crop. The purpose of this study is to apply information technology to determine and determine the superior types of rice that can improve crop yields and rice quality. The method that the researchers chose was the AHP method combined with the WP method. The reason for the AHP method was chosen because it was able to analyze criteria that had good consistency values. Whereas WP is chosen because it has the ability to analyze alternatives to be a form of ranking with a quick and easy process. Based on the results of the analysis of the combination of AHP and WP that has been done, the AHP method is able to produce priority factors which are the weight values for the WP method ranking. And the WP method produces the highest ranking of superior rice seeds with a value of 0.204 .
\end{abstract}

Keywords: Rice Seeds, SPK, AHP, WP

\begin{abstract}
Abstrak: Beras menjadi kebutuhan utama dalam mengolah berbagai macam makanan terutama nasi. Kebutuhan beras dari tahun ke tahun pun semakin tinggi. Hal demikian membuat para petani harus meningkatkan produktifitas padi yang akan ditanam. Akan tetapi petani masih menggunakan cara coba-coba dan mengandalkan kebiasaan turun temurun dalam menentukan benih padi yang ditanam. Sebagai contoh masih ada petani memilih benih padi berdasarkan harga benih yang murah dan yang memiliki masa panen lebih cepat. Dampaknya mengurangi harga jual hasil panen.Adapun tujuan penelitian ini adalah menerapkan teknologi informasi untuk mengetahui dan menentukan jenis padi yangunggul yang dapat meningkatkan hasil panen dan kualitas padi. Metode yang peneliti pilih adalah metode AHP yang dikombinasikan dengan metode WP. Alasan metode AHP dipilih karena mampu menganalisis kriteria yang memiliki nilai konsistensi yang baik. Sedangkan WP dipilih karena memiliki kemampuan menganalisis alternative menjadi bentuk perangkingan dengan proses yang cepat dan mudah. Berdasarkan hasil analisis dari kombinasi AHP dan WP yang telah dilakukan, metode AHP mampu menghasilkan faktor prioritas yang menjadi nilai bobot untuk perankingan metode WP. Dan metode WP menghasilkan perankingan tertinggi benih padi unggul dengan nilai 0,204.
\end{abstract}

Kata Kunci : Benih Padi,SPK, AHP, WP 
DOI: https://doi.org/10.33330/jurteksi.v6i1.391

Available online at http://jurnal.stmikroyal.ac.id/index.php/jurteksi

\section{PENDAHULUAN}

Beras merupakan bahan pokok yang banyak diminati masyarakat. Beras menjadi kebutuhan utama dalam mengolah berbagai macam makanan terutama nasi. Kebutuhan beras dari tahun ke tahun pun semakin tinggi. Hal demikian membuat para petani harus meningkatkan produktifitas padi yang akan ditanam. Upaya yang dapat dilakukan selain memperbanyak lahan pertanian yang belum produktif menjadi persawahan adalah menerapkan teknologi dalam segala lini pertanian. Hal ini untuk menunjang meningkatnya hasil panen.Salah satunya menerapkan teknologi untuk menentukan benih padi unggul.

Dalam menentukan benih padi yang akan ditanam, selama ini petani masih menggunakan cara cobacoba.Dampaknya, terkadang petani mengalami masalah kurang maksimal dalam hasil panen dikarenakan bobot (tonase) dan kualitas butir nasi rendah, biaya perawatan lebih banyak, masa panen lama, hingga yang terburuk yaitu gagal panen.

Begitupun petani di Desa Silo Maraja Kabupaten Asahan yang menjadi lokasi observasi, petani masih menggunakan cara coba-coba dan mengandalkan kebiasaan turun temurun dalam menentukan benih padi yang ditanam. Sebagai contoh masih ada petani memilih benih padi berdasarkan harga benih yang murah dan yang memiliki masa panen lebih cepat. Namun hal tersebut berpengaruh pada yaitu bobot butir padi menjadi lebih ringan/kecil sehingga tonase padi lebih sedikit. Selain tonase yang lebih sedikit hal itu juga berpengaruh pada kualitas padi yang dihasilkan.Dampaknya mengurangi harga jual hasil panen.

Berdasarkan uraian masalah di atas, peneliti berkeinginan melakukan penelitian penerapan teknologi untuk menentukan benih unggul dalam rangka meningkatkan hasil panen.Teknologi yang digunakan melalui kombinasi 2 metode yaitu metode Analitical Hierarchy Process (AHP) dan Metode Weight Product (WP).Kedua metode ini merupakan bagian dari Sistem Pendukung Keputusan.AHP dipilih karena mampu menganalisis kriteria yang memiliki nilai konsistensi. Sedangkan WP dipilih karena memiliki kemampuan memproses alternative menjadi bentuk perangkingan dengan proses yang cepat dan mudah.

\section{Benih Padi}

Benih padi merupakan gabah yang dihasilkan dari proses panen yang ditujukan untuk digunakan bahan tanam dalam usahatani. Benih yang unggul cenderung menghasilkan produk dengan kualitas yang baik. Semakin unggul benih komoditas pertanian, semakin tinggi produksi pertanian yang akan dicapai [1].

\section{Sistem Pendukung Keputusan}

Menurut Komalasari (2018) SPK bertujuan untuk meningkatkan proses serta hasil dalam sebuahpenentuan keputusan. Sistem Pendukung Keputusan memberdayakan kemampuan personal dengan kecerdasan dan kecanggihan komputer untuk membantu manajemen dalam mendapatkan keputusan yang yang berkualitas. Bentuk masalah yang diukur adalah masalah semi terstruktur maupun yang tidak terstruktur [7].

Sedangkan menurut Muktadir (2013) SPK dapat ddefenisikan sebagai sistem pendukung keputusanyang didukung menggunakan faslitas kecanggihan komputer yang dibangun mengacu pada interface yang dapat 
DOI: https://doi.org/10.33330/jurteksi.v6i1.391

Available online at http://jurnal.stmikroyal.ac.id/index.php/jurteksi

dipahami pengguna.

Berdasarkan uraian di atas kompleksitas sistem secara fisik menuntut adanya sistem keputusan yang komplek pula. Ciri utama dari sistem pendukung keputusan adalah kemampuannya untuk menyelesaikan masalahmasalah yang tidak terstruktur. Pada dasarnya system pendukung keputusan merupakan pengembangan lebih lanjut dari sistem manajemen terkomputerisasi yang dirancang sedemikian rupa sehingga bersifat interaktif dengan pemakainya. Sifat interaktif ini dimaksudkan untuk memudahkan integrasi antara berbagai komponen dalam proses pengambilan keputusan seperti prosedur, kebijakan, teknis, analisis, serta pengalaman dan wawasan manajerial guna membentuk suatu kerangka keputusan yang bersifat fleksibel

\section{Analytical Hierarchy Process (AHP)}

Analytic Hierarchy Process merupakan teori umum yang digunakan untuk pengukuran dalam rangka mengetahui skala rasio dari skala perbandingan berpasangan yang kontinyu atau diskrit. AHP menyelesaikan bentuk masalah yang multi kriteria dan kompleks menjadi suatu bentuk hirarki [2].

Metode Analytic Hierarchy Process(AHP) merupakan salah satu metode dalam proses pengambilan keputusan. Metode ini digunakan untuk mendukung pengambilan keputusan terhadap beberapa alternatif pilihan. Proses pengambilan keputusan diawali dengan menetapkan faktorfaktor/kriteria yang mempengaruhi pengguna dalam mengambil keputusan. Pengguna memberikan prioritas terhadap sepasang kriteria (pairwise comparison). Jika setiap pasangan kriteria sudah ditetapkan skala prioritasnya, maka data prioritas tsb dimodelkan dalam sebuah matriks [3]. Adapun prosedur dalam metodeAHP meliputi:

1. Mendefinisikan masalah dalam bentuk hirarki.

2. Menentukan prioritas elemen Matriks perbandingan berpasangan menggunakan bilangan 1-9 untuk mempresentasikan kepentingan relatif dari suatu elemen terhadap elemen yang lainnya.

3. Sintesis

Pertimbangan terhadap perbandingan berpasangan disintesis untuk memperoleh keseluruhan prioritas.

4. Mengukur konsistensi

Bertujuan untuk mendapatkan pertimbangan pada sebuah kriteria dengan konsistensi yang baik.

HitungConsistencyRatio(CR)denga $n$ rumus $: \mathrm{CR}=\mathrm{CI} / \mathrm{IR}$, Dimana :

$\mathrm{CR}=$ ConsistencyRatio

$\mathrm{CI}=$ ConsistencyIndex , $\mathrm{CI}=(\lambda$ maks $-\mathrm{n}) / \mathrm{n}, \quad$ Dimanan = banyaknya elemen

IR = IndeksRandom

5. Memeriksa konsistensi hirarki.

Jika nilainya $\mathrm{CR}<=0,1$ maka nilai konsistensi sudah baik, sedangkan jika $\mathrm{CR}>0,1$ Maka penilaian data judgment harus diperbaiki

\section{Metode Weighted Product (WP)}

Metode WP adalah metode untuk pengambilan keputusan berdasarkan besarnya nilai preferensi yang dihitung berdasarkan pada nilai variabel yang digunakan yang dipangkatkan dengan bobotnya. Semakin besar nilai preserensi suatu alternatif solusi maka alternatif solusi itu semakin disukai [4].

Preferensi untuk alternatif $\mathrm{Ai}$ diberikan sebagai berikut:

$$
S_{i}=\prod_{j=1}^{n} x_{i j}{ }^{w_{j}}
$$

dengan $\mathrm{i}=1,2, \ldots, \mathrm{m}$; dimana $\sum \mathrm{wj}=1$ 
DOI: https://doi.org/10.33330/jurteksi.v6i1.391

Available online at http://jurnal.stmikroyal.ac.id/index.php/jurteksi

wj adalah pangkat bernilai positif untuk atribut keuntungan, dan bernilai negatif untuk atribut biaya. Untuk perangkingan / mencari alternatif yang terbaik dilakukan dengan rumus berikut:

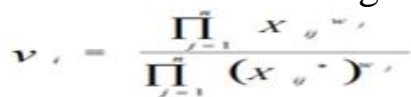

Nilai Vi yang terbesar menyatakan bahwa alternatif Ai terpilih

\section{METODE}

Adapun kerangka kerja dari penelitian ini yaitu sebagai berikut :

1. Kajian Pustaka

Dimaksudkan untuk mempelajari dan memahami ruang lingkup permasalahan benih padi unggul melalui referensi jurnal dan prosiding penerapan metode AHP dan WP.

2. Proses Pengumpulan Data

Pada tahap ini dilakukan pengumpulan data pada lokasi penelitian, melalui pemberian angket kepada pakar yang memahami alteranatif dan kriteria benih padi unggul, wawancara maupun observasi guna melengkapi data yang dibutuhkan

3. Penerapan Metode AHP dan WP

Dilakukan proses analisis data dengan metode AHP dan WP untuk mendapatkan perankingan benih padi unggul.

\section{HASIL DAN PEMBAHASAN}

Berdasarkan hasil dari pengumpulan data yang telah dilakukan, adapun kriteria dari pemilihan benih padi unggul yang akan diterapkan kedalam metode AHP yaitu sebagai berikut :
Tabel 1. Kriteria

\begin{tabular}{cl}
\hline Kriteria & \multicolumn{1}{c}{ Keterangan } \\
\hline C1 & Umur Tanaman \\
C2 & Bentuk Tanaman \\
C3 & Tekstur Nasi \\
C4 & Bobot Butir \\
C5 & Rata-rata Hasil \\
C6 & Potensi Hasil \\
C7 & Ketahanan terhadap hama \\
\hline
\end{tabular}

Selanjutnya, untuk menganalisa kriteria yang sudah dikumpulkan tersebut dimulai dari membentuk matriks perbandingan kriteria berikut :

\section{Tabel 2. Matriks Perbandingan}

\section{Kriteria}

\begin{tabular}{cccccccc}
\hline & $\mathrm{C} 1$ & $\mathrm{C} 2$ & $\mathrm{C} 3$ & $\mathrm{C} 4$ & $\mathrm{C} 5$ & $\mathrm{C} 6$ & $\mathrm{C} 7$ \\
\hline $\mathrm{C} 1$ & 1 & 6 & 3,000 & 9,000 & 0,333 & 6,000 & 4,000 \\
$\mathrm{C} 2$ & 0,167 & 1 & 0,17 & 3,00 & 0,13 & 0,33 & 0,50 \\
$\mathrm{C} 3$ & 0,333 & 6,000 & 1 & 7 & 0,5 & 4 & 2 \\
$\mathrm{C} 4$ & 0,111 & 0,333 & 0,143 & 1 & 0,13 & 0,5 & 0,25 \\
$\mathrm{C} 5$ & 3,000 & 8,000 & 2 & 8 & 1 & 8 & 6 \\
$\mathrm{C6} 6$ & 0,167 & 3,000 & 0,25 & 2 & 0,13 & 1 & 0,3333 \\
$\mathrm{C} 7$ & 0,250 & 2,000 & 0,5 & 4 & 0,17 & 3 & 1 \\
JLH & 5,028 & 26,333 & 7,060 & 34,000 & 2,375 & 22,833 & 14,083 \\
\hline
\end{tabular}

Setelah membentuk matrik perbandingan kriteria, selanjutnya menghitung setiap elemen dengan jumlah elemen dan mencari nilai ratarata dari masing-masing kriteria berdasarkan nilai jumlah dari sintesis dibagi dengan jumlah kriteria yang akan menjadikan landasan dalam perankingan kriteria. Maka membentuklah tabel sintesis yang akan dijadikan landasan mengenai gambaran dari faktor/kriteria berikut ini.

Selanjutnya proses perhitungan Consistensi Rasio (CR). CI $=(\lambda$ maks$\mathrm{n}) / \mathrm{n}$, Di mana $\mathrm{n}=$ banyaknya elemen $\lambda$ maks $=(0,2577 * 5,028)+(0,0408 * 26,333$ )$+(0,1671 * 7,060)+(0,0252 * 34,000)+(0$, $3738 * 2,375)+(0,0516 * 22,833)+(0,0838$ 
Vol. VI No. 1, Des 2019, hlm. 19 - 24

DOI: https://doi.org/10.33330/jurteksi.v6i1.391

Available online at http://jurnal.stmikroyal.ac.id/index.php/jurteksi

$* 14,083)=7,65 \mathrm{n} \quad=7, \mathrm{CI}=(7,65-7)$

/ $7=0,11$

$\mathrm{IR}=1,32$. Karena $\mathrm{n}=7$

$\mathrm{CR}=\mathrm{CI} / \mathrm{IR}=0,11 / 1,32=0,0827$

Berdasarkan nilai $\mathrm{CR}=0,0827$, maka dapat disimpulkan bahwa hasil tersebut memenuhi syarat $\mathrm{CR}<0,1 \quad$ yaitu konsisten.

\section{Tabel 3. Sistesis Perbandingan} Kriteria

\begin{tabular}{ccccccccc}
\hline \multicolumn{1}{c}{ Jumlah Setiap Elemen } & & $\begin{array}{c}\text { Jum } \\
\text { lah }\end{array}$ & $\begin{array}{l}\text { Ra } \\
\text { ta- } \\
\text { Ra } \\
\text { ta }\end{array}$ \\
\hline 0,1 & 0,2 & 0,4 & 0,2 & 0,1 & 0,2 & 0,2 & 1,80 & 0,2 \\
99 & 28 & 25 & 65 & 40 & 63 & 84 & 4 & 58 \\
0,0 & 0,0 & 0,0 & 0,0 & 0,0 & 0,0 & 0,0 & 0,28 & 0,0 \\
33 & 38 & 24 & 88 & 53 & 15 & 36 & 6 & 41 \\
0,0 & 0,2 & 0,1 & 0,2 & 0,2 & 0,1 & 0,1 & 1,16 & 0,1 \\
66 & 28 & 42 & 06 & 11 & 75 & 42 & 9 & 67 \\
0,0 & 0,0 & 0,0 & 0,0 & 0,0 & 0,0 & 0,0 & 0,17 & 0,0 \\
22 & 13 & 20 & 29 & 53 & 22 & 18 & 7 & 25 \\
0,5 & 0,3 & 0,2 & 0,2 & 0,4 & 0,3 & 0,4 & 2,61 & 0,3 \\
97 & 04 & 83 & 35 & 21 & 50 & 26 & 7 & 74 \\
0,0 & 0,1 & 0,0 & 0,0 & 0,0 & 0,0 & 0,0 & 0,36 & 0,0 \\
33 & 14 & 35 & 59 & 53 & 44 & 24 & 1 & 52 \\
0,0 & 0,0 & 0,0 & 0,1 & 0,0 & 0,1 & 0,0 & 0,58 & 0,0 \\
50 & 76 & 71 & 18 & 70 & 31 & 71 & 7 & 84 \\
\hline
\end{tabular}

Tabel 4. Bobot Preferensi

\begin{tabular}{|c|c|c|c|c|c|c|c|}
\hline $\mathrm{C} 1$ & C & & C3 & C4 & C5 & C6 & C7 \\
\hline 0,258 & 0,0 & & 0,167 & 0,025 & 0,374 & 0,052 & 0,08 \\
\hline \multicolumn{8}{|c|}{ Tabel 5. Nilai Alternatif dan Kriteria } \\
\hline & $\mathrm{C} 1$ & $\mathrm{C} 2$ & $\mathrm{C} 3$ & $\mathrm{C} 4$ & $\mathrm{C} 5$ & C6 & $\mathrm{C} 7$ \\
\hline A1 & 3 & 5 & 3 & 4 & 3 & 2 & 2 \\
\hline A2 & 4 & 5 & 4 & 5 & 2 & 2 & 3 \\
\hline A3 & 5 & 3 & 3 & 5 & 2 & 3 & 4 \\
\hline A4 & 4 & 5 & 3 & 4 & 5 & 3 & 3 \\
\hline A5 & 3 & 5 & 2 & 3 & 4 & 3 & 3 \\
\hline A6 & 4 & 3 & 4 & 3 & 3 & 4 & 5 \\
\hline
\end{tabular}

Hasil dari metode AHP diatas dalam bentuk faktor prioritas akan menjadi bobot preferensi dari metode WP. Proses penelitian selanjutnya adalah menentukan alternatif-alternatif padi unggul dan kriterianya untuk mendapat benih padi unggul. Sampel alternatif diuraikan dalam A1 sampai A6 yang berarti ada 6 alternatif yang akan diproses menggunakan metode WP untuk perankingan.

Selanjutnya menghitung nilai vektor S, dengan pangkatkan dan kalikan nilai dari masing-masing kriteria dengan bobot preferensi yaitu sebagai berikut dengan inisial masing-masing alternatif S1 sampai S6 berikut ini:

$$
\begin{aligned}
\mathrm{S} 1= & \left(3^{0,258}\right) *\left(5^{0,041}\right) *\left(3^{0,167}\right) *\left(4^{0,025}\right)^{*} \\
& \left(3^{0,074}\right) *\left(2^{0,052}\right) *\left(2^{0,084}\right) \\
& =2,921 \\
\mathrm{~S} 2 & =\left(4^{0,258}\right) *\left(5^{0,041}\right) *\left(4^{0,167}\right) *\left(5^{0,025}\right)^{*} \\
& \left(2^{0,074}\right) *\left(2^{0,052}\right) *\left(3^{0,084}\right) \\
& =2,951 \\
\mathrm{~S} 3= & \left(5^{0,258}\right) *\left(3^{0,041}\right) *\left(3^{0,167}\right) *\left(5^{0,025}\right)^{*} \\
& \left(2^{0,074}\right) *\left(3^{0,052}\right) *\left(4^{0,084}\right) \\
& =3,052 \\
\mathrm{~S} 4 & =\left(4^{0,258}\right) *\left(5^{0,041}\right) *\left(3^{0,167}\right) *\left(4^{0,025}\right)^{*} \\
& \left(5^{0,074}\right)^{*}\left(3^{0,052}\right) *\left(3^{0,084}\right) \\
& =4,022 \\
\mathrm{~S} 5 & =\left(3^{0,258}\right) *\left(5^{0,041}\right) *\left(2^{0,167}\right) *\left(3^{0,025}\right)^{*} \\
& \left(4^{0,074}\right)^{*}\left(3^{0,052}\right) *\left(3^{0,084}\right) \\
& =3,187
\end{aligned}
$$

S6 $=\left(4^{0,258}\right) *\left(3^{0,041}\right) *\left(4^{0,167}\right) *\left(3^{0,025}\right)^{*}$ $\left(3^{0,074}\right) *\left(4^{0,052}\right) *\left(5^{0,084}\right)$ $=3,591$

Maka dari perhitungan diatas, terbentuklah tabel vektor $S$ dari 6 alternatif berikut :

\section{Tabel 6. Nilai Vektor S Alternatif}

\begin{tabular}{cc}
\hline Vektor S & Hasil \\
\hline S1 & 2,921 \\
S2 & 2,951 \\
S3 & 3,052 \\
S4 & 4,022 \\
S5 & 3,187
\end{tabular}

Selanjutnya menghitung nilai vektor yang digunakan untuk menghitung preferensi (Vi) untuk proses perankingan. Perhitungan tersebut sebagai berikut :

$V 1$

$=\frac{2,921}{2,921+2,951+3,052+4,022+3,187+3,591}$ 
DOI: https://doi.org/10.33330/jurteksi.v6i1.391

Available online at http://jurnal.stmikroyal.ac.id/index.php/jurteksi

$$
\begin{aligned}
& =0,148 \\
& \text { V2 } \\
& =\frac{2,951}{2,921+2,951+3,052+4,022+3,187+3,591} \\
& =0,150 \\
& \text { V3 } \\
& =\frac{3,052}{2,921+2,951+3,052+4,022+3,187+3,591} \\
& =0,155 \\
& \text { V4 } \\
& =\frac{4,022}{2,921+2,951+3,052+4,022+3,187+3,591} \\
& =0,204 \\
& \text { V5 } \\
& =\frac{3,187}{2,921+2,951+3,052+4,022+3,187+3,591} \\
& =0,162 \\
& \text { V6 } \\
& =\frac{3,591}{2,921+2,951+3,052+4,022+3,187+3,591} \\
& =0,182
\end{aligned}
$$

Maka dari perhitungan diatas proses perankingan dengan metode WP sebagai berikut :

Tabel 7. Perankingan

\begin{tabular}{ccc}
\hline Vektor & Hasil & Ranking \\
\hline V1 & 0,148 & 6 \\
V2 & 0,150 & 5 \\
V3 & 0,155 & 4 \\
V4 & 0,204 & 1 \\
V5 & 0,162 & 3 \\
V6 & 0,182 & 2 \\
\hline
\end{tabular}

\section{SIMPULAN}

Adapun kesimpulan dari proses penelitian ini adalah :

1. Metode AHP dapat membantu menganalisis kriteria prioritas yang konsisten dalam pemilihan benih padi unggul.

2. Dalam menganalis pemililihan benih padi unggul, metode WP berhasil menentukan alternatif terbaik berdasarkan faktor prioritas pemilihan benih padi unggul. Alternatif yang paling tertinggi dengan nilai vektor 0,204 merupakan benih padi yang paling unggul.

\section{UCAPAN TERIMA KASIH}

Ucapan terima kasih kepada DRPM Direktorat Jenderal Penguat Riset dan Pengembangan Kementrian Riset, Teknologi dan Pendidikan Tinggi Sesuai dengan Kontrak Penelitian PDP Tahun Anggaran 2019.

\section{DAFTAR PUSTAKA}

[1] Notarianto, D., \& PUJIYONO, A. (2011). Analisis efisiensi penggunaan faktor-faktor produksi pada usahatani padi organik dan padi anorganik (studi kasus: Kecamatan Sambirejo, Kabupaten Sragen) (Doctoral dissertation, Universitas Diponegoro).

[2] Darmanto, E., Latifah, N., \& Susanti, N. (2014). Penerapan metode AHP (Analythic Hierarchy Process) untuk menentukan kualitas gula tumbu. Simetris: Jurnal Teknik Mesin, Elektro dan Ilmu Komputer, 5(1), 75-82.

[3] Padmowati, R. D. L. E. (2015, July). Pengukuran Index Konsistensi Dalam proses Pengambilan Keputusan Menggunakan Metode AHP. In Seminar Nasional Informatika (SEMNASIF) (Vol. 1, No. 5).

[4] Supriyono, H. (2015). Pemilihan rumah tinggal menggunakan metode weighted product. Khazanah Informatika: Jurnal Ilmu Komputer dan Informatika, 1(1), 23-28. 